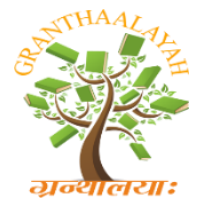

$$
\begin{aligned}
& \text { INTERNATIONAL JOURNAL OF RE } \\
& \text { GRANTHAALAYAH } \\
& \text { A knowledge Repository }
\end{aligned}
$$

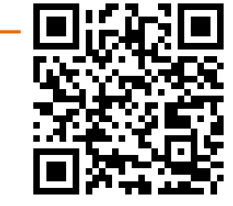

Science

\title{
REVIEW OF VIRECHANA KARMA IN CLASSICAL TEXTS OF AYURVEDA
}

\author{
Dr. Ganesh Dipak Mali ${ }^{1}$, Dr. Shivprasad Mehtre ${ }^{2}$ \\ ${ }^{1,2}$ Associate Professor, Rural Institute of Ayurveda Research Center and Hospital, Mayani, Dist. \\ Satara, India
}

\begin{abstract}
The Ayurvedic management of diseases consists of Shodhana and Shamana treatments. Shodhana Chikitsa is performed mainly by employing Panchakarma, it includes, Vamana, Virechana, Asthapana Basti, Anuvasana Basti and Nasyakarma. Virechana is considered as the best treatment for morbid and increased Pitta Dosha. This paper serves as a collection of references pertaining to Virechana Karma during ancient period of Ayurveda Samhitas, along with some information on the method of Virechana Karma explained in ancient textbooks of Ayurveda Samhitas.
\end{abstract}

Keywords: Shodhana; Panchakarma; Virechana; Purgation.

Cite This Article: Dr. Ganesh Dipak Mali, and Dr. Shivprasad Mehtre. (2020). "REVIEW OF VIRECHANA KARMA IN CLASSICAL TEXTS OF AYURVEDA." International Journal of Research - Granthaalayah, 8(1), 250-265. 10.29121/granthaalayah.v8.i1.2020.278.

\section{Introduction}

The Ayurvedic management of diseases in general, can be broadly grouped in to Shodhana and Shamana treatments. The former is intended to eliminate excessively vitiated Doshas out of the body and there by eradicates disease as a whole, while the later is directed towards palliation of vitiated Doshas. However, Ayurvedic classics unequally give paramount importance to the Shodhana therapy, owing to its credential of providing a complete cure. Acharya Charaka says that Doshas subdued by Langhana and Pachana therapies may provoke, but in case of Shodhana, there is seldom possibility of such recurrence.[1]

The Shodhana has got no parlance in the modern medicine, but we can say that the toxins and metabolic toxic products responsible for the disease are eliminated from the body. Shodhana Chikitsa is performed mainly by employing Panchakarma, it includes- Vamana, Virechana, Asthapana Basti, Anuvasana Basti and Nasyakarma.[2]

In the classics the Shodhana is specially indicated in Bahudoshavastha as a curative measure, in Rutucharya as preventive measure and prior to Rasayana Prayoga as a promotive measure.[3] 
Virechana is less stressful procedure than Vamana Karma. It has less possibility of complications and could be done easily. So it is widely used as Shodhana therapy in routine. It is more acceptable to all classes of patients. In an addition to the acceptability and popularity, the Virechana is considered as the best treatment for morbid and increased Pitta Dosha.

\section{Objectives}

To collect references of Virechana Karma explaned in Ancient Ayurveda Samhitas and to establish the method of Virechana Karma practiced in Samhita Kaala.

\section{Material and Methods}

This paper serves as a collection of references pertaining to Virechana Karma during ancient period of Ayurveda Samhitas, along with some information on the method of Virechana Karma explained in ancient textbooks of Ayurveda Samhitas.

\section{Virechana Karma}

\section{Etymological Consideration}

The word Virechana has three components. (Vachaspatyam 4847)

- Vi - Upasarga (prefix)

- Richir - Rich Dhatu (root)

- Lut - Pratyaya (suffix) (Maladi Nissaranam) Here 'Richir' - evacuation

Rich - Viyojana (separation)

Samparchana (combination)

The words 'Praskandana' and 'Rechana' are also used for Virechana Karma in classics.

\section{Definition}

Tatradoshaharanam Adhobhagam Virechana Sangyakam/ Cha.Ka. 1/4, The act of expelling Doshas through 'Adhobhaga' is known as Virechana.[4]

\section{Karyakshetra (site of action) of Virechana Dosha}

Pitta, Pitta Sthanagata Alpa Kapha, Kapha Sthanagata Bahu Pitta, Pittavrita Vata, Sannipatika condition. (Bhela)

\section{Dushya \\ Rasa, Rakta, Mamsa, Asthi, Majja, Shukra.}

\section{Strotas}

Rasavaha, Raktavaha, Mamsavaha, Asthivaha, Majjavaha.

In all the above Dhatu Vikaras Virechana is described in direct or indirect way.[5][6] 
Table 1: Virechana Yogya Roga [7],[8],[9],[10]

\begin{tabular}{|c|c|c|c|c|c|c|}
\hline \multicolumn{7}{|c|}{$\begin{array}{l}\text { Virechana Yogya Ch.Sa } \\
\text { Pitta Pradhana Vyadhi }\end{array}$} \\
\hline Jwara & + & + & + & + & + & + \\
\hline Pandu & + & + & - & - & + & + \\
\hline Kamla & + & - & - & + & - & - \\
\hline Halimaka & + & - & + & + & - & - \\
\hline Netradaha & + & + & - & - & - & - \\
\hline Asyadaha & + & + & - & - & - & - \\
\hline Paittik vyadhi & + & + & + & - & - & - \\
\hline \multicolumn{7}{|c|}{ Vata Pradhana Vyadhi } \\
\hline Pakvashaya Ruja & - & + & + & + & - & - \\
\hline Shirahshoola & + & - & + & - & - & - \\
\hline Parshvaruja & + & - & - & - & - & - \\
\hline Gulma & + & + & + & + & + & + \\
\hline Vatarakta & + & + & + & + & + & + \\
\hline \multicolumn{7}{|c|}{ Kapha Pradhana Vyadhi } \\
\hline Prameha & + & + & - & - & + & + \\
\hline Netrasrava & + & - & - & - & + & + \\
\hline Asyasrava & + & - & - & - & + & + \\
\hline Nasasrava & + & - & - & - & + & + \\
\hline Swasa & + & - & - & - & - & - \\
\hline Kshavathu & + & - & - & - & - & - \\
\hline Kasa & + & + & - & - & + & + \\
\hline \multicolumn{7}{|c|}{ Tridoshaja Vyadhi } \\
\hline Kushtha & + & + & - & - & + & + \\
\hline Visarpa & + & + & - & - & - & - \\
\hline
\end{tabular}

\begin{tabular}{|c|c|c|c|c|c|c|}
\hline Hridroga & 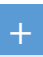 & 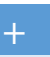 & & 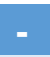 & + & + \\
\hline \multicolumn{7}{|c|}{ Rakta Pradhana Vyadhi } \\
\hline Pliha & + & + & + & + & + & + \\
\hline Vyang & & 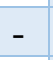 & + & + & - & 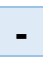 \\
\hline Nilika & & 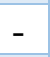 & & 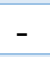 & 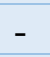 & 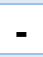 \\
\hline Visp & 1 & + & + & + & + & - \\
\hline \multicolumn{7}{|c|}{ Manasa Roga } \\
\hline Unmada & + & & - & - & 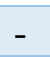 & - \\
\hline & $T$ & + & - & - & - & - \\
\hline \multicolumn{7}{|c|}{ Striroga } \\
\hline Yonidosha & + & + & + & + & + & 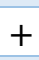 \\
\hline \multicolumn{7}{|c|}{ Shalya Kriya Sadhya Vyadhi } \\
\hline Arbuda & + & + & - & - & - & 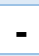 \\
\hline Bhagand & + & + & + & - & + & + \\
\hline Arsha & + & + & + & + & + & + \\
\hline Vidr & - & + & + & + & + & + \\
\hline
\end{tabular}




\begin{tabular}{|l|c|c|c|c|c|c|}
\hline Granthi & + & + & - & - & + & + \\
\hline Galaganda & + & - & - & - & - & - \\
\hline Bradhna & + & - & - & - & - & - \\
\hline Dushtavrana & - & + & + & + & - & + \\
\hline Vriddhi & - & + & - & - & - & - \\
\hline \hline Apachi & + & - & - & - & - & - \\
\hline
\end{tabular}

\section{Shalakya Vyadhi

\begin{tabular}{|c|c|c|c|c|c|c|}
\hline Timira & + & + & + & + & - & \\
\hline Abhishyanda & - & + & + & + & - & \\
\hline Kacha & - & + & + & + & - & \\
\hline Akshipaka & - & + & + & - & - & \\
\hline
\end{tabular}

Annavaha Srotas

\begin{tabular}{|l|c|c|c|c|c|c|}
\hline Krimikoshtha & + & + & + & + & + & + \\
\hline Garvisha & - & + & - & + & + & + \\
\hline Visuchika & + & + & - & - & + & + \\
\hline Alasaka & + & + & - & - & - & - \\
\hline Udara & + & - & + & + & + & + \\
\hline Arochaka & + & + & - & - & + & + \\
\hline Avipaka & + & + & - & - & + & + \\
\hline Vibandha & - & + & + & + & - & - \\
\hline Anaha & - & + & - & - & - & - \\
\hline Margabheda & & & & & & \\
\hline U.Raktapitta & + & + & + & + & - & - \\
\hline Udavarta & + & - & + & - & - & - \\
\hline Chhardi & + & + & + & + & + & + \\
\hline Others & & & & & & \\
\hline Retodosha & + & - & + & + & - & - \\
\hline Mutraghata & + & + & + & + & + & + \\
\hline
\end{tabular}

\section{Shastrakshat a \\ \begin{tabular}{|l|l|l|l|l|l|l|}
\hline Ksharagni dagdha & - & + & + & - & - & - \\
\hline
\end{tabular}}

Table 2: Virechana Ayogya Roga

\begin{tabular}{|l|c|c|c|c|c|c|}
\hline Virechana Yogya & Ch.Sa & Su.Sa & As.Sa & As.Hr & Sh & BP \& YR \\
\hline Incapable to tolerate the stress of therapy & & & \\
\hline Vilambita & + & - & + & - & - & - \\
\hline Durabala & + & - & - & - & - & - \\
\hline Durbalendriy a & + & - & - & - & - & - \\
\hline Upavasita & + & - & - & - & - & - \\
\hline Subhaga & + & - & - & - & - & - \\
\hline Alpagni & + & + & + & + & + & + \\
\hline Abhihata & + & - & - & - & - & - \\
\hline
\end{tabular}




\begin{tabular}{|l|c|c|c|c|c|c|}
\hline Kshatakshina & + & + & + & - & + & + \\
\hline Shrant & + & + & - & - & + & + \\
\hline Pipasita & + & + & - & - & + & + \\
\hline Karma & + & + & - & - & - & - \\
Bharadhvaha ta & & & & & & \\
\hline Vruddha & + & - & - & - & + & + \\
\hline Bala & + & + & + & - & - & - \\
\hline Atikrisha & + & - & + & - & + & - \\
\hline Atisthula & + & + & + & - & + & - \\
\hline
\end{tabular}

\begin{tabular}{|l|l|l|l|l|l|l|}
\hline Daruna koshtha & + & - & + & + & - & - \\
\hline Kshama & + & - & - & - & - & - \\
\hline Garbhini & + & + & - & - & - & - \\
\hline Bhakta & + & + & - & - & + & - \\
\hline Riktakoshtha & - & - & - & - & - & - \\
\hline Lalita & - & - & - & - & - & - \\
\hline Sukumar & - & - & - & - & - & - \\
\hline Navprasuta & - & + & - & - & + & + \\
\hline
\end{tabular}

Some other conditions

\begin{tabular}{|l|c|c|c|c|c|c|}
\hline Ratrijagarana & - & - & + & - & - & - \\
\hline Ravati & - & - & - & - & - & - \\
\hline Anupsnigdha & - & - & - & - & - & - \\
\hline Atisnigdha & + & + & - & + & + & + \\
\hline Atiruksha & + & - & - & - & + & + \\
\hline Bhayopatapt a & - & + & - & - & + & + \\
\hline Chintaprasak ta & + & - & - & - & + & + \\
\hline Maithunapra sakta & + & - & - & - & - & - \\
\hline Adhyayanapr asakta & + & - & - & - & - & - \\
\hline Vyayamapras akta & + & + & + & + & + & + \\
\hline Shalyardita & + & - & + & + & - & - \\
\hline Shosha & - & - & - & + & - & - \\
\hline
\end{tabular}

\begin{tabular}{|c|c|c|c|c|c|c|}
\hline Kamadivyagr aha & + & + & - & - & - & - \\
\hline Niruda & + & - & - & - & - & - \\
\hline \multicolumn{7}{|c|}{ Samavastha } \\
\hline Navapratishy aya & - & + & - & - & - & - \\
\hline Navajwara & + & + & + & + & + & + \\
\hline \multicolumn{7}{|c|}{ Disease of the rectum } \\
\hline Kshataguda & + & + & + & - & - & - \\
\hline Muktanala & + & - & + & - & - & - \\
\hline \multicolumn{7}{|c|}{ Margavirodhi vyadhi } \\
\hline Adhogarakta pitta & + & + & + & + & - & - \\
\hline Atisara & - & - & - & + & - & - \\
\hline
\end{tabular}




\begin{tabular}{|l|c|c|c|c|c|c|}
\hline \multicolumn{7}{|c|}{ Other diseases } \\
\hline Madatyaya & + & + & + & - & + & + \\
\hline Adhamana & + & + & + & - & - & - \\
\hline Talushosha & - & - & - & - & - & - \\
\hline Urusthambha & - & - & - & - & - & - \\
\hline Ardita & - & - & - & - & - & - \\
\hline Hanugraha & - & - & - & - & - & - \\
\hline Hridroga & - & - & - & - & - & - \\
\hline Kevala Vataroga & - & - & - & - & - & - \\
\hline Rajayakshma & - & - & + & - & - & - \\
\hline
\end{tabular}

\section{Classification of Virechana Drugs}

According to the references the Virechana drugs may be classified in following groups; Virechana drugs according to their origin and parts used [11],[12]

Animal Origin - Urine, Milk, Takra (Butter milk)

\section{Plant Origin -}

Mulini Drugs - The roots of the plants, which have been recommended for Virechana are Hastidanti, Shyamatrivrita, Adhoguda (Vidhara), Saptala, Pratyagasreni (Danti), Gavakshi, Vishanika, Ajagandha, Pravanti, Kshirini, Shankhini, Sruk, Svarnakshiri, Chitraka, Kinhi, Kusha and Kasha, Vacha, Hrasva Panchamula, both Punarnava, Vastak, Shak, Shala.

Phalani Drugs - Phalini drugs are mainly Shankhini, Vidanga, Anupa Klitaka, Sthalaja Klitaka, Abhaya, Antahkoterpushpi, Kampillaka and Aragwadha, Puga, Haritaki, Amalaki, Vibhitaki, Nilini, Chaturangula, Eranda, Kampillaka, Pilu, Priyal, Kubala, Badara, Karkandu, Kasmarya, Parusaka, Draksha etc.

Kshirini Drugs - Snuhi and Arka, Saptachhada, Jyotishmati.

Tvak - Barks of Putika, Tilvaka, Kampillaka, Ramyaka Patla etc.

\section{Virechana Drugs According to Their Mode of Action [13]}

Acharya Sharangadhara has classified the drugs from their mode of action. A group of drugs known as 'Virechanopaga' mentioned by Acharya Charaka, which may also beaded to this classification, as a fifth group.

Anulomana: The drugs, which move the Malas downwords after digestion and breaking their bandha, are known as Anulomana. e.g. Haritaki

Sransana: The literary meaning of Sransana is to slip or to fall down. The drugs, which bring the semi- digested and sticky Malas without causing their digestion is known as Sransana. e.g. Aragvadha.

Bhedana: The Drugs which disintegrate the Abaddha (unformed) or Baddha (formed) or Pindita (dried focal mass) forms of Malas by facilitating penetration into it and then evacuating through the lower gut is known as Bhedana e.g. Katuki. Acharya Charaka has described a group of drug named as Bhedaniya. This includes Suvaha (Trivrit), Arka, Urubuka (Eranda), Agnimukhi (Kalihari), Chitra (Danti), Chitraka, Chirabilva, Sanhini, Shakuladani (Katuki) and Svarnakshiri. 
Rechana: The drugs which eliminates Pakvam (digested) and Apakvam (undigested) Malas or Doshas by making them watery through the lower gut is known as Rechana. e.g. Trivrut.

Virechanopaga: The Virechanopaga Gana described in Charaka Samhita has been considered as helping in inducing Virechana. These are Draksha, Kasmarya, Parusaka, Abhaya, Amalaki, Bibhitaki, Badara, Karkandu and Pilu.

\section{Virechana Drugs According to Intensity of Action}

Mrudu Virechana: The Drugs, which are Manda in Virya, when combined with opposite Virya or given in low dose, given to Ruksha patient and causing less purgation is known as Mrudu Virechana. Charaka has the view that the physician should not hesitate to use Mrudu Virechana drugs in weak patients having more Doshas because repeated elimination of Doshas in small quantity may cure the disease.[14]

The patient who have not taken Virechana Drugs in past and whose Kostha is unknown in such patients Sushruta recommended the use of Mrudu Virechana drugs in the beginning and after knowing the Kostha required drug may be prescribed.[15]

Sharangadhara recommended that the Mrudu Virechana drugs i.e. Draksha, milk, warm water, castor oil etc. should be used in Mrudu Koshthi patient.[16] Drugs effective in Mrudu Koshta are Guda, Sugar cane juice, Mastu, Ulloditadadhi, Payas, Kshira, Sarpi, Kashmari, Triphala, Pilu and Tarunamadya.[17]

Madhya Virechana: The drugs which are moderate in qualities are known as Madhya Virechana drugs. These drugs are specifically indicated in the patients having Madhya Roga (disease with moderate symptoms). The administration of these drugs in Balavana patient is useless, because they are unable to eliminate Dosha completely.[18]

Sharangadhara recommended the use of Trivrut, Katuki and Aragvadha for Madhya Kostha.[19]

Tikshna Virechana: The drugs which cause Mahavega (numerous motions) and eliminates the Doshas in large quantity by Kshipra (quick) and gentle purgation causing neither much Glani (depression) nor pain in heart area or anus nor harmful to internal organs, is known as Tikshna Virechana.

Acharya Charaka recommended the use of these drugs in the Balvana Rogi, presenting all the symptoms of the disease i.e. Tikshana Vyadhi.[20] Snuhi Kshira is the best Tikshana Virechana drug among those drugs.[21]

\section{Virechana From Ruksha And Snigdha Point of View}

The drugs which are used in the form of oil or the preparation containing Sneha is known as Sneha Virechana e.g. Castor oil. Vagbhatta recommended the use of Sneha Virechana in all patients except Snigdha patient.[22] The use of Sneha Virechana in the patients who have taken higher dosage of Sneha is contraindicated because due to this the movable Doshas may again adhere in the Srotas.[23] The preparations, which do not contain Sneha, can be used as Ruksha Virechana. It has been recommended on the Snigdha patients who have comparatively taken more Sneha.[24] 


\section{According to Kalpana}

This is for maintenance of active principle for longer period and convenience of taking drugs as Churna, Vartikriya, Asava, Arishta, Avaleha, Sneha and Kashaya. According to Sushruta following 8 preparations are useful, Ghruta Yoga, Taila Yoga, Kshira Yoga, Madhya Yoga, Mutra Yoga, Mansarasa Yoga, Bhakshana Yoga and Avaleha Yoga. Kshira,

Rasa, Kalka, Kashaya, Kwatha, Shita are Laghu in descending order.[25]

Table 3: Virechana drugs according to season [26]

\begin{tabular}{|c|c|c|}
\hline Rutu & Preparation & Anupana \\
\hline Varsha & $\begin{array}{l}\text { Trivrut Kutajabeej Pippali } \\
\text { Shunthi }\end{array}$ & Draksha Rasa Madhu \\
\hline \multirow[t]{8}{*}{ Sharad } & Trivrut & Draksa \\
\hline & Duralabha & decoction \\
\hline & Musta & \\
\hline & Sharkara & \\
\hline & Usheer & \\
\hline & Chandana & \\
\hline & Satala & \\
\hline & Yashtimadhu & \\
\hline \multirow[t]{7}{*}{ Hemant } & Trivrut & Ushna \\
\hline & Chitraka & Jala \\
\hline & Patha & \\
\hline & Jivaka & \\
\hline & Sarala & \\
\hline & Vacha & \\
\hline & Hemakshiri & \\
\hline \multirow[t]{4}{*}{$\begin{array}{l}\text { Shishir \& } \\
\text { Vasanta }\end{array}$} & $\begin{array}{l}\text { Trivrut } \\
\text { Pippali }\end{array}$ & Madhu \\
\hline & Nagara & \\
\hline & Sindhu & \\
\hline & Shyama & \\
\hline Grishma & Trivrut & Sharkara \\
\hline All Seasons & Trivrut Danti Hapusha Saptala Katuki Swarna- & Gomutra \\
\hline
\end{tabular}

\section{Dosage of Virechana Drugs}

While describing the process of Virechana the dose of Trivrut mentioned is one Aksha (Tola).[27]

Table 4: According to Sharangadhara[28]

\begin{tabular}{|c|c|c|c|}
\hline Kalpana & Hina for Mrudu Kostha & $\begin{array}{l}\text { Madhyama for } \\
\text { Madhyama Kostha }\end{array}$ & $\begin{array}{l}\text { Uttam for } \\
\text { Krura Kostha }\end{array}$ \\
\hline Kwatha & 2 Tola & 4 Tola & 8 Tola \\
\hline $\begin{array}{l}\text { Kalka, Churna, } \\
\text { Modaka. }\end{array}$ & 1 Tola & 2 Tola & 4 Tola \\
\hline
\end{tabular}


It is better to add Madhu before using these preparations.

\section{According to Koshtha[29]}

Mrudu, Madhyam and Tikshna Matras are mentioned for Mrudu, Madhyama and Krura Kostha respectively.

\section{Procedure of Virechana Karma}

This includes administration of Virechana Yogas, observation especially for Aushadha Jirnata, observation of Shuddhi Lakshanas and management of Vyapada if occurs.

\section{Administration of Virechana Yoga}

The Virechana Yoga is given to the patient

- After Samyaka Snehana and Svedana.

- While the patient is cheerful, slept well and has fully digested his previous meal.

- After assessing the psychological condition of the patient (Manasamabhisamikshya).

- Krita Homa, Bali etc. on Ishta Tithi, Muhurta.

- After Swastivachana.

- Virechana performed on empty stomach.[30]

- About the time of giving Virechana, Vagbhatta mentioned 'Shleshma Kalagate' means after passing Shleshma Kala i.e. after 10 A.M. but not before 9 A.M. in any case.[31]

\section{Observations}

\section{Aushadha Jirna Lakshana}

Aushadha Jirna Lakshana are Vatanulomana, Swasthya, Kshudha, Trishna, Urja, Manasvita, Indriya Laghuta.

\section{Hrita Dosha Lakshana}

The Virechana is considered as Kaphanta and Hritadosha when come out with Pitta and Kapha one by one in sequence. Gatradaurbalya and Laghuta are the associated symptoms.[32]

\section{Shuddhi Lakshana}

Four types of Shuddhi viz. Laingiki, Antiki, Vaigiki and Maniki should be observed according to Chakrapani, but the importance should be given to Laingiki Shuddhi.

Table 5: Antiki, Vaigiki and Maniki Shuddhi in Virechana Karma [33]

\begin{tabular}{|l|l|l|l|}
\hline Shuddhi & Pravara & \multicolumn{1}{|c|}{ Madhyama } & A vara \\
\hline Vaigiki & 30 Vega & 20 Vega & 10 Vega \\
\hline Maniki & 4 Prastha & 3 Prastha & 2 Prastha \\
\hline Antiki & Kaphanta & Kaphanta & Kaphanta \\
\hline
\end{tabular}


Laingiki Shuddhi Lakshanas according to Acharyas are as follows,

Table 6: Samyaka Yoga Lakshana of Virechana Karma [34][35][36]

\begin{tabular}{|l|c|c|c|}
\hline Lakshana & Charaka & Sushruta & Vagbhata \\
\hline Indriya / Buddhi Prasada & + & + & + \\
\hline Stroto Vishuddhi & + & - & - \\
\hline Laghuta & + & - & + \\
\hline Agnivriddhi & + & + & - \\
\hline Anamayatva & + & - & + \\
\hline Kramat vit-Pitta- Kapha Agamana & + & - & + \\
\hline Vata Anulomana & + & - & + \\
\hline
\end{tabular}

Table 7: Ayoga Lakshana of Virechana Karma [37][38][39]

\begin{tabular}{|l|c|c|c|}
\hline Lakshana & Charaka & Sushruta & Vaghohata \\
\hline Kapha Prakopa & + & + & + \\
\hline Pitta Prakopa & + & + & + \\
\hline Vata Prakopa & + & - & - \\
\hline Agnimandya & + & + & - \\
\hline Gaurava & + & + & - \\
\hline Pratishyaya & + & - & + \\
\hline Tandra & + & - & - \\
\hline Chhardi & + & - & - \\
\hline Aruchi & + & + & + \\
\hline Vata Pratilomana & + & - & Vata \\
\hline Daha & & & vigraha \\
\hline Hridaya Ashuddhi & - & + & + \\
\hline Kukshi Ashuddhi & - & + & + \\
\hline Kandu & - & + & + \\
\hline Vitsanga & + & + & + \\
\hline Mutrasanga & - & + & - \\
\hline \hline Pidika & - & - & + \\
\hline
\end{tabular}

Table 8: Atiyoga Lakshana of Virechana [40][41][42]

\begin{tabular}{l|c|c|c|}
\hline Lakshana & Charaka & Sushruta & Vagbhata \\
\hline Kapha Kshaya Vikara & + & + & - \\
\hline Pitta Kshaya Vikara & + & - & - \\
\hline Vata Kshaya Vikara & + & - & - \\
\hline Supti & + & - & - \\
\hline Agnimandya & + & - & - \\
\hline Klama & + & - & - \\
\hline Vepathu & + & - & - \\
\hline Nidra & + & - & - \\
\hline Balabhava & + & - & - \\
\hline
\end{tabular}




\begin{tabular}{|l|c|c|c|}
\hline Tamah Pravesha & + & - & - \\
\hline Unmada & + & - & - \\
\hline Hikka & + & - & - \\
\hline Murchha & - & + & - \\
\hline Gudabhransha & - & - & - \\
\hline Kapha-Pitta Rahita Udaka Nihasarana & - & - & - \\
\hline Kapha-Pitta Rahita Lohita Nihasarana & - & - & + \\
\hline Mamsa Dhavanavata Udaka Srava & - & - & + \\
\hline Medokhandavat Srava & - & - & + \\
\hline Trushna & - & - & + \\
\hline Bhrama & - & - & + \\
\hline Netrapravesha & - & - & + \\
\hline Raktakshayaja Vikara & + & - & - \\
\hline
\end{tabular}

Table 9: Virechana Vyapada with their treatment [43]

\begin{tabular}{|c|c|c|}
\hline \multirow{2}{*}{$\begin{array}{l}\text { Vyapada } \\
\text { Adhmana }\end{array}$} & Lakshana & Chikitsa \\
\hline & $\begin{array}{l}\text { Adhmana, Udavart, Nabhi, } \\
\text { Prustha, } \\
\text { Parshva, }\end{array}$ & $\begin{array}{l}\text { Abhyanga, Sveda, Phalavarti, } \\
\text { Niruha, } \\
\text { Anuvasana, Udavarthara }\end{array}$ \\
\hline & $\begin{array}{l}\text { Shiraruja, Swasa, Vit-Mutra- } \\
\text { Vata Sanga }\end{array}$ & Chikitsa \\
\hline $\begin{array}{l}\text { Parikartika } \\
\text { I } \\
\text { II } \\
\text { III }\end{array}$ & $\begin{array}{l}\text { Gudaparikartan Tivrashula, } \\
\text { Piccha } \\
\text { Rakta Mala Pravrutti }\end{array}$ & $\begin{array}{l}\text { Laghana,Pachana } \\
\text { Ruksha Ushna } \\
\text { Bhojan Yastimadhu Sneha } \\
\text { Basti }\end{array}$ \\
\hline Paristrava & $\begin{array}{l}\text { Alpamala Pravrutti, } \\
\text { Kandu, Shopha, Kustha } \\
\text { Gaurava, Agnimandya } \\
\text { Staimitya, Aruchi, Pandu }\end{array}$ & $\begin{array}{l}\text { Alpa Shamana Vamana,Virechana } \\
\text { Grahani Chikitsa Asava, Arishta }\end{array}$ \\
\hline Hridgraha & $\begin{array}{l}\text { Hikka, Swasa, Kasa } \\
\text { Parshvashula, Lalasrava } \\
\text { Akshivibhrama, Shula } \\
\text { Dantakitkitayan, Sadnyanasha }\end{array}$ & $\begin{array}{l}\text { Snigdha Lavana Sveda,Yasti Taila } \\
\text { Anuvasana,Tikshn Nasya,Vamana } \\
\text { Basti }\end{array}$ \\
\hline Angagraha & $\begin{array}{l}\text { Stambha,Vepathu, Toda } \\
\text { Pindikodveshtana } \\
\text { Manthanavata Pida }\end{array}$ & $\begin{array}{l}\text { Vataharachikitsa Snehana } \\
\text { Svedana }\end{array}$ \\
\hline Jivadana & $\begin{array}{l}\text { Raktachandrikayu kta } \\
\text { Udakasrava Gudabhransha, } \\
\text { Trishna Murchha, Mada }\end{array}$ & $\begin{array}{l}\text { Pittaharachikitsa } \\
\text { Raktapana,Raktab asti, } \\
\text { Pichha Basti Ghritamanda Anuvasan } \\
\text { Basti }\end{array}$ \\
\hline
\end{tabular}




\begin{tabular}{|c|c|c|}
\hline $\begin{array}{l}\text { Vibhransh } \\
\text { a. Guda } \\
\text { b. Sanjya } \\
\text { c. Kanduadi }\end{array}$ & $\begin{array}{l}\text { Only mala } \\
\text { excreted not } \\
\text { Doshas, shodhana } \\
\text { occur Gudabhransha Sangya } \\
\text { Bhransha Kandu, Pidika } \\
\text { Kustha roga }\end{array}$ & $\begin{array}{l}\text { Kashaya lepa } \\
\text { Snehana } \\
\text { mrudusveda Manoanukul chi. } \\
\text { Tikshna shodhana } \\
\text { after snehapana }\end{array}$ \\
\hline Stambha & $\begin{array}{l}\text { Vatavarodha Gudastambha, } \\
\text { Gudshula } \\
\text { Alpa-mala pravrutti }\end{array}$ & $\begin{array}{l}\text { Langhana, Pachana Tikshna Basti } \\
\text { Virechana }\end{array}$ \\
\hline Updrava & $\begin{array}{l}\text { Stambha, Gatragraha, } \\
\text { Sarvanga Vedana, Shula }\end{array}$ & Snehana, Svedana Vatahara Chikitsa \\
\hline Klama & $\begin{array}{l}\text { Tandra, Gaurava, Klama } \\
\text { Daurbalya, Angasada }\end{array}$ & $\begin{array}{l}\text { Langhana, Pachana Snehana, } \\
\text { Tikshana } \\
\text { Shodhana }\end{array}$ \\
\hline $\begin{array}{l}\text { Vamana by } \\
\text { Virechana Yoga }\end{array}$ & Vamana & Snehana Svedana Virechana \\
\hline Ayogya & $\begin{array}{l}\text { Vibhransha, Hikka, } \\
\text { Pindikodveshtana, Kandu, } \\
\text { Urahshula } \\
\text { Vaivarnyata }\end{array}$ & $\begin{array}{l}\text { Roganusara Chikitsa } \\
\text { Gomutra Niruhana }\end{array}$ \\
\hline Atiyoga & Ati-Virechana & $\begin{array}{l}\text { Mrudu Vamana Raktapittahara } \\
\text { Vatahara Chikitsa }\end{array}$ \\
\hline
\end{tabular}

\section{Mode of action of Virechana}

Action of Virechana Karmas can be divided in the following two ways.

1) Systemic - By which it brings down the morbid Doshas, particularly Pitta from the Amashaya or Pakvashaya, i.e. G.I.T.

2) Local evacuant - It is concerned with the evacuation of these Doshas in the form of Malas from the gut by purgation.

Both the action and related factors are being described here in detail.

Virechana drugs gets absorbed and due to Virya, it reaches to the Hridaya (heart) then the Dhamanis and then after reaches to Sthula and Anu Srotas i.e. macro and micro channels of the body.

- The Vyavayi Guna of drug is responsible for quick absorption.

- The Vikasi Guna causes softening and loosing of the Bandha.

- Due to Ushna Guna, the Dosha Sanghata (compactness) is liquefied (Vishyandana).

- Action of Tikshna Guna is to break the Mala and Dosha in micro forms. According to Dalhana it is responsible for quick excretion.

- Due to Sukshma Guna, by reaching in micro channels, disintegrates endogenic toxins, which are then excreted through micro-channels (Anupravanabhava).

- Due to Prabhava mainly and also due to Pruthavi Jala constitution, finally Virechana occurs. This is the evacuation action.[44] 


\section{Discussion}

Samhitas are oldest source of knowledge written before 3000 BC and which provide thorough knowledge of Ayurveda in Sanskrita. Samhitas guided us very well towards different subjects but Shodhana and Shamana therapies were primarily focused to treat various types of diseases. It became clear from screening of Samhitas that Shodhana therapies were widely elaborated but the references found in scattered manner. Out of five, Virechana is less stressful procedure. It has less possibility of complications and could be done easily. So, it is widely used as Shodhana therapy in routine. It is more acceptable to all classes of patients. In addition to the acceptability and popularity, the Virechana is considered as the best treatment for morbid and increased Pitta Dosha. So, it is the need of time to collect all references of Virechana at one place and to get its thorough knowledge at a glance.

\section{Conclusion}

Reviewing Samhitas revealed that use of Shodhana therapies especially Virechana is found to be used since long time. It is generally thought that Ayurveda classics i.e., Samhitas such as Charaka, Sushruta and Vagbhata have their major role in contribution of body detoxification procedures i.e., Shodhana therapies. From having looked at references mentioned in above article, it is clear that Samhitas dealt significantly in development of Shodhana therapies. Unfortunately, due to scattered form of references of Virechana, it has become difficult to establish proper method of body detoxification procedures. Therefore, it has become necessity to study Samhitas from various point of view of Ayurveda. This research paper was an attempt to study from Virechana perspective. Scholars would be delighted to know how immense research one can carry out in these Samhitas and bring new knowledge in front of the world.

\section{References}

[1] Vaidya Yadavaji Trikamji Acharya editor Charak Samhita of Agnivesha elaborated by Charaka \& Drudhabala by Chakrapanidatta, Sutrasthana 16/20, Chaukhamba Surabharati Prakashan, Varanasi, 2009:97

[2] Vaidya Yadavaji Trikamji Acharya editor Charak Samhita of Agnivesha elaborated by Charaka \& Drudhabala by Chakrapanidatta, Sutrasthana 2/7-15, Chaukhamba Surabharati Prakashan, Varanasi, 2009:24-25

[3] Vaidya Yadavaji Trikamji Acharya editor Charak Samhita of Agnivesha elaborated by Charaka \& Drudhabala by Chakrapanidatta, Sutrasthana 7/46, Chaukhamba Surabharati Prakashan, Varanasi, 2009:53

[4] Vaidya Yadavaji Trikamji Acharya editor Charak Samhita of Agnivesha elaborated by Charaka \& Drudhabala by Chakrapanidatta, Kalpasthana 1/4, Chaukhamba Surabharati Prakashan, Varanasi, 2009:651

[5] Vaidya Yadavaji Trikamji Acharya editor Charak Samhita of Agnivesha elaborated by Charaka \& Drudhabala by

[6] Chakrapanidatta, Sutrasthana 28/25, Chaukhamba Surabharati Prakashan, Varanasi, 2009:179

[7] Vaidya Yadavaji Trikamji Acharya editor Charak Samhita of Agnivesha elaborated by Charaka \& Drudhabala by Chakrapanidatta, Sutrasthana 22/18, Chaukhamba Surabharati Prakashan, Varanasi, 2009:121 
[8] Vaidya Yadavaji Trikamji Acharya editor Charak Samhita of Agnivesha elaborated by Charaka \& Drudhabala by Chakrapanidatta, Siddhisthana 2/11-13, Chaukhamba Surabharati Prakashan, Varanasi, 2009:688

[9] Vaidya Yadavaji Trikamji Acharya editor Sushrut Samhita of Sushrut with the Nibandhasangraha commentary of Shri Dalhanacharya, Chikitsasthana 33/29-32, Chaukhamba Surabharati Prakashan, Varanasi, 2012:519

[10] Pa.Hari Sadashiv Shastri Paradkar editor Ashtang Hridaya of Vagbhat with the Sarvangsundara of Arundatta \& Ayurvedarasayana of Hemadri, Sutrasthana 18/8-11, Chaukhamba Surabharati Prakashan, Varanasi, 2010:261

[11] Dr. Brahmanand Tripathi editor Sharandhara Samhita of Pa. Sharandharacharya annoted with Dipika Hindi commentary, Uttarkhanda 4/1-7, Chaukhamba Surabharati Prakashan, Varanasi, 2006:342-343

[12] Vaidya Yadavaji Trikamji Acharya editor Charak Samhita of Agnivesha elaborated by Charaka \& Drudhabala by Chakrapanidatta, Sutrasthana 1/74-119, Chaukhamba Surabharati Prakashan, Varanasi, 2009:20-22

[13] Vaidya Yadavaji Trikamji Acharya editor Sushrut Samhita of Sushrut with the Nibandhasangraha commentary of Shri Dalhanacharya, Sutrasthana 39/4, Chaukhamba Surabharati Prakashan, Varanasi, 2012:170

[14] Dr. Brahmanand Tripathi editor Sharandhara Samhita of Pa. Sharandharacharya annoted with Dipika Hindi commentary, Purvakhanda 4/3-6, Chaukhamba Surabharati Prakashan, Varanasi, 2006:46-47

[15] Vaidya Yadavaji Trikamji Acharya editor Charak Samhita of Agnivesha elaborated by Charaka \& Drudhabala by Chakrapanidatta, Kalpasthana 12/56-58 \& 67-69, Chaukhamba Surabharati Prakashan, Varanasi, 2009:673-674

[16] Vaidya Yadavaji Trikamji Acharya editor Sushrut Samhita of Sushrut with the Nibandhasangraha commentary of Shri Dalhanacharya, Chikitsasthana 33/44, Chaukhamba Surabharati Prakashan, Varanasi, 2012:520

[17] Dr. Brahmanand Tripathi editor Sharandhara Samhita of Pa. Sharandharacharya annoted with Dipika Hindi

[18] commentary, Uttarkhanda 4/13-14, Chaukhamba Surabharati Prakashan, Varanasi, 2006:344

[19] Vaidya Yadavaji Trikamji Acharya editor Charak Samhita of Agnivesha elaborated by Charaka \& Drudhabala by Chakrapanidatta,, Sutrasthana 13/66-67, Chaukhamba Surabharati Prakashan, Varanasi, 2009:85

[20] Vaidya Yadavaji Trikamji Acharya editor Charak Samhita of Agnivesha elaborated by Charaka \& Drudhabala by Chakrapanidatta,, Kalpasthana 12/55-68, Chaukhamba Surabharati Prakashan, Varanasi, 2009:673-674

[21] Dr. Brahmanand Tripathi editor Sharandhara Samhita of Pa. Sharandharacharya annoted with Dipika Hindi commentary, Uttarkhanda 4/13-14, Chaukhamba Surabharati Prakashan, Varanasi, 2006:344

[22] Vaidya Yadavaji Trikamji Acharya editor Charak Samhita of Agnivesha elaborated by Charaka \& Drudhabala by Chakrapanidatta,, Kalpasthana 12/58, Chaukhamba Surabharati Prakashan, Varanasi, 2009:673

[23] Vaidya Yadavaji Trikamji Acharya editor Charak Samhita of Agnivesha elaborated by Charaka \& Drudhabala by Chakrapanidatta,, Sutrasthana 25/40, Chaukhamba Surabharati Prakashan, Varanasi, 2009:131

[24] Pa.Hari Sadashiv Shastri Paradkar editor Ashtang Hridaya of Vagbhat with the Sarvangsundara of Arundatta \& Ayurvedarasayana of Hemadri, Sutrasthana 18/54, Chaukhamba Surabharati Prakashan, Varanasi, 2010:269 
[25] Vaidya Yadavaji Trikamji Acharya editor Sushrut Samhita of Sushrut with the Nibandhasangraha commentary of Shri Dalhanacharya, Chikitsasthana 33/41, Chaukhamba Surabharati Prakashan, Varanasi, 2012:520

[26] Vaidya Yadavaji Trikamji Acharya editor Charak Samhita of Agnivesha elaborated by Charaka \& Drudhabala by Chakrapanidatta,, Siddhisthana 6/9, Chaukhamba Surabharati Prakashan, Varanasi, 2009:704

[27] Vaidya Yadavaji Trikamji Acharya editor Sushrut Samhita of Sushrut with the Nibandhasangraha commentary of Shri Dalhanacharya, Sutrasthana 44/90-91, Chaukhamba Surabharati Prakashan, Varanasi, 2012:195

[28] Vaidya Yadavaji Trikamji Acharya editor Charak Samhita of Agnivesha elaborated by Charaka \& Drudhabala by Chakrapanidatta,, Kalpasthana 7/56-60, Chaukhamba Surabharati Prakashan, Varanasi, 2009:664

[29] Vaidya Yadavaji Trikamji Acharya editor Charak Samhita of Agnivesha elaborated by Charaka \& Drudhabala by

[30] Chakrapanidatta,, Sutrasthana 15/17, Chaukhamba Surabharati Prakashan, Varanasi, 2009:95

[31] Dr. Brahmanand Tripathi editor Sharandhara Samhita of Pa. Sharandharacharya annoted with Dipika Hindi commentary, Uttarkhanda 4/16-17, Chaukhamba Surabharati Prakashan, Varanasi, 2006:344

[32] Vaidya Yadavaji Trikamji Acharya editor Sushrut Samhita of Sushrut with the Nibandhasangraha commentary of Shri Dalhanacharya, Chikitsasthana 33/21, Chaukhamba Surabharati Prakashan, Varanasi, 2012:518

[33] Vaidya Yadavaji Trikamji Acharya editor Charak Samhita of Agnivesha elaborated by Charaka \& Drudhabala by Chakrapanidatta,, Sutrasthana 15/17, Chaukhamba Surabharati Prakashan, Varanasi, 2009:95-96

[34] Pa.Hari Sadashiv Shastri Paradkar editor Ashtang Hridaya of Vagbhat with the Sarvangsundara of Arundatta \& Ayurvedarasayana of Hemadri, Sutrasthana 18/33, Chaukhamba Surabharati Prakashan, Varanasi, 2010:266

[35] Vaidya Yadavaji Trikamji Acharya editor Charak Samhita of Agnivesha elaborated by Charaka \& Drudhabala by Chakrapanidatta,, Sutrasthana 16/5-6, Chaukhamba Surabharati Prakashan, Varanasi, 2009:96

[36] Vaidya Yadavaji Trikamji Acharya editor Charak Samhita of Agnivesha elaborated by Charaka \& Drudhabala by Chakrapanidatta,, Siddhisthana 1/14, Chaukhamba Surabharati Prakashan, Varanasi, 2009:679

[37] Vaidya Yadavaji Trikamji Acharya editor Charak Samhita of Agnivesha elaborated by Charaka \& Drudhabala by Chakrapanidatta,, Siddhisthana 1/17-18, Chaukhamba Surabharati Prakashan, Varanasi, 2009:680

[38] Pa.Hari Sadashiv Shastri Paradkar editor Ashtang Hridaya of Vagbhat with the Sarvangsundara of Arundatta \& Ayurvedarasayana of Hemadri, Sutrasthana 18/25, Chaukhamba Surabharati Prakashan, Varanasi, 2010:264

[39] Vaidya Yadavaji Trikamji Acharya editor Sushrut Samhita of Sushrut with the Nibandhasangraha commentary of Shri Dalhanacharya, Chikitsasthana 33/23, 25, 27, Chaukhamba Surabharati Prakashan, Varanasi, 2012:518-519

[40] Vaidya Yadavaji Trikamji Acharya editor Charak Samhita of Agnivesha elaborated by Charaka \& Drudhabala by Chakrapanidatta,, Siddhisthana 1/18-19, Chaukhamba Surabharati Prakashan, Varanasi, 2009:680

[41] Vaidya Yadavaji Trikamji Acharya editor Sushrut Samhita of Sushrut with the Nibandhasangraha commentary of Shri Dalhanacharya, Chikitsasthana 33/24, Chaukhamba Surabharati Prakashan, Varanasi, 2012:518 
[42] Pa.Hari Sadashiv Shastri Paradkar editor Ashtang Hridaya of Vagbhat with the Sarvangsundara of Arundatta \& Ayurvedarasayana of Hemadri, Sutrasthana 18/38-39, Chaukhamba Surabharati Prakashan, Varanasi, 2010:267

[43] Vaidya Yadavaji Trikamji Acharya editor Charak Samhita of Agnivesha elaborated by Charaka \& Drudhabala by Chakrapanidatta,, Siddhisthana 1/19-20, Chaukhamba Surabharati Prakashan, Varanasi, 2009:680

[44] Vaidya Yadavaji Trikamji Acharya editor Sushrut Samhita of Sushrut with the Nibandhasangraha commentary of Shri Dalhanacharya, Chikitsasthana 33/24, Chaukhamba Surabharati Prakashan, Varanasi, 2012:518

[45] Pa.Hari Sadashiv Shastri Paradkar editor Ashtang Hridaya of Vagbhat with the Sarvangsundara of Arundatta \& Ayurvedarasayana of Hemadri, Sutrasthana 43.

[46] 18/40-41, Chaukhamba Surabharati Prakashan, Varanasi, 2010:267

[47] Vaidya Yadavaji Trikamji Acharya editor Charak Samhita of Agnivesha elaborated by Charaka \& Drudhabala by Chakrapanidatta,, Siddhisthana 6/29-93, Chaukhamba Surabharati Prakashan, Varanasi, 2009:705-709

[48] Vaidya Yadavaji Trikamji Acharya editor Charak Samhita of Agnivesha elaborated by Charaka \& Drudhabala by Chakrapanidatta, Kalpasthana 1/5, Chaukhamba Surabharati Prakashan, Varanasi, 2009:651

*Corresponding author.

E-mail address: drganeshmali@gmail.com 